\section{Comparison of Rambutan Quality after Hot Forced-air and Irradiation Quarantine Treatments}

\author{
Peter A. Follett ${ }^{1}$ and Suzanne S. Sanxter \\ U.S. Department of Agriculture, Agricultural Research Service, U.S. Pacific \\ Basin Agricultural Research Center, P.O. Box 4459, Hilo, HI 96720
}

\section{Additional index words. Nephelium lappaceum, postharvest treatment, fruit flies, Hawaii}

\begin{abstract}
Insect disinfestation treatments are required for many of Hawaii's tropical fruits before export to the U.S. mainland. For rambutan, Nephelium lappaceum L., irradiation at 250 Gy is an Animal Plant Health Inspection Service (APHIS)-approved quarantine treatment, but a hot forced-air treatment has also been proposed for eliminating fruit fly pests. Two days after harvest, rambutan fruit (cultivars R134 and R167) were subjected to: 1) hot forced-air at a seed surface temperature of $47.2{ }^{\circ} \mathrm{C}, 2$ ) irradiation treatment at $250 \mathrm{~Gy}$, or 3 ) left untreated as controls. Fruit were then stored at $10^{\circ} \mathrm{C}$ in perforated plastic bags, and quality attributes were evaluated after 4,8 , and 12 days. ' $R 134$ ' fruit treated with hot forced-air were significantly darker (lower $L^{*}$ ) and less intensely colored (lower $C^{*}$ ) than irradiated or nontreated fruits after 4 and 8 days of posttreatment storage; the external appearance was unacceptable after 4 days of storage, whereas irradiated fruit remained acceptable through 8 days of storage. Differences between treatments were less pronounced for 'R167'. 'R167' fruit treated with hot forced-air had lower $L^{*}$ and $C^{*}$ values and less acceptable external appearance ratings than did irradiated fruit at 4,8 , and 12 days posttreatment, but differences were not statistically significant. For both cultivars, external appearance of fruit in all treatments was unacceptable after 12 days of storage, whereas taste was rated as acceptable for all treatments on each day. Overall, under these experimental conditions, irradiation was superior to hot forced-air as a quarantine treatment on the basis of fruit quality maintenance.
\end{abstract}

Rambutan is a tropical evergreen tree fruit native to Malaysia and Indonesia and is distributed widely in humid, high rainfall areas of Southeast Asia (Nakasone and Paull, 1998; Watson, 1988). Malaysia and Thailand currently are the major exporting countries. The tree belongs to the family Sapindaceae, which includes litchi (Litchi chinensis Sonn.) and longan (Dimocarpus longan Lour.). Rambu$\tan$ is sometimes called the "hairy" litchi because of the fruit's red coloring and flexible hair-like protuberances, called spinterns (Watson, 1988; Zee et al., 1998). Fruit of most rambutan cultivars are red when ripe, but some are yellow or pink (Watson, 1988). Rambutan is a nonclimacteric fruit, and its flavor and sweetness do not improve after harvest (Lam

Received for publication 30 Nov. 1999. Accepted for publication 16 Apr. 2000. Mention of a trademark, warranty, proprietary product, or vendor does not constitute a guarantee by the U.S. Dept. of Agriculture and does not imply its approval to the exclusion of other products or vendors that may be suitable. Louis Aung, Gil Simmons, and Krista Shellie provided critiques of an early draft of the manuscript that greatly improved its clarity and focus. The help of Zona Gabbard and Robert Lower during fruit quality analysis is greatly appreciated. We appreciate the cooperation of Kahili Farmers, Inc., who harvested and shipped fruit to us for this study. The cost of publishing this paper was defrayed in part by the payment of page charges. Under postal regulations, this paper therefore must be hereby marked advertisement solely to indicate this fact.

${ }^{1}$ To whom reprint requests should be addressed. E-mail address: pfollett@pbarc.ars.usda.gov et al., 1987; Paull and Chen, 1987; Zee et al., 1998). In Hawaii, rambutan is one of the main cialty fruit industry.

There is substantial commercial interest in exporting fresh rambutans to the U.S. mainland. Rambutans, like many other tropical fruits grown in Hawaii, are under a federal quarantine because the fruit is a potential host of the Mediterranean fruitfly, Ceratitis capitata (Wiedemann), and the oriental fruit fly, Bactrocera dorsalis Hendel. These pests are not established in the continental United States, and commodity quarantine treatments ensure that the risk of exporting them from Hawaii is minimized.

Two quarantine treatments have been developed for exporting rambutans from Hawaii to the U.S. mainland. Irradiation with a minimum absorbed dose of $250 \mathrm{~Gy}$ is an U.S. Dept. of Agriculture (USDA)-APHIS-approved treatment for disinfestation of fruit flies for eight fruits exported from Hawaii, including rambutan. Since 1995, various tropical fruits, including rambutan, have been flown from Hawaii to the U.S. mainland for irradiation treatment and subsequent distribution and sale. This practice is expensive because of the limited number of treatment facilities and their distances from major markets. An e-beam/ converted X-ray facility has recently been constructed in Hawaii, and other irradiation facilities may be forthcoming if market interests grow. A hot forced-air treatment, consisting of heating fruit to a seed surface temperature of $47.2^{\circ} \mathrm{C}$ in not less than $1 \mathrm{~h}$ and holding crops of the rapidly expanding tropical spe- for $20 \mathrm{~min}$, has also been developed for rambutan and is in the final stages of approval by USDA-APHIS. Hawaii has numerous hot forced-air facilities that primarily serve the papaya (Carica papaya L.) export industry, and these could also be used to treat rambutan as soon as a hot forced-air treatment is approved. The purpose of this study was to make a direct comparison of the effects of these two postharvest treatments on rambutan quality.

\section{Materials and Methods}

Rambutan fruit were obtained from Kahili Farmers, Inc., during a commercial harvest on the island of Kauai, Hawaii, from Jan. to Apr. 1999. Immediately after harvest, fruit were processed on an automated fruit processor (KW Engineering, Queensland, Australia) that included roller and conveyor belt feeders and a 10-brush wash unit with low-pressure overhead water spray nozzles. Fruit were then packaged in perforated plastic bags (Cryovac Australia, Fawkner, Victoria), placed in fiberboard boxes, and air freighted without refrigeration to the USDA-ARS laboratory in Hilo, on the island of Hawaii. One day after harvest, fruit without culls were randomized for treatments. Baseline quality analyses were performed on fruit samples before initiation of quarantine treatments. The second day after harvest, fruit were treated with one of two quarantine treatments: hot forced-air (HFA) or irradiation (IRR), or left untreated as controls. A factorial experimental design consisting of three treatments (control, irradiation, hot forced-air) $\times$ three storage intervals $(4,8$, 12 d) was used for each of two rambutan cultivars ('R167', 'R134')independently. Each cultivar, first 'R167', then 'R134', was harvested ripe on the tree on four successive weeks, and each harvest date constituted a replicate. Ripe 'R167' and 'R134' rambutan fruit characteristically have a red/orange to crimson pericarp and red spinterns with green tips (Fig. 1).

Hot forced-air treatment. Tests were conducted at the USDA-ARS laboratory in Hilo using a computer-controlled hot forced-air treatment chamber specifically designed for research on postharvest hot air treatments of fresh tropical commodities (Gaffney and Armstrong, 1990). The chamber could be programmed for a ramp to a desired target internal fruit temperature, and humidity could be regulated via injection of water vapor from a steam generator. The HFA treatment used in our study involved heating the fruit to a seed surface (fruit center) temperature of $47.2^{\circ} \mathrm{C}$ in $1 \mathrm{~h}$ and holding at $47.2^{\circ} \mathrm{C}$ for $20 \mathrm{~min}$. This treatment was developed by Phillips et al. (USDA-ARS, unpublished data) for the disinfestation of fruit flies. Eight large rambutan fruit of each replicate were probed individually with thermocouples at the seed surface to monitor fruit center temperature. Additional thermocouples were used to monitor the temperature of air entering and exiting the HFA chamber, and the temperature at the outer surface of the pericarp of the fruit. The temperature of the incoming air did not exceed the 


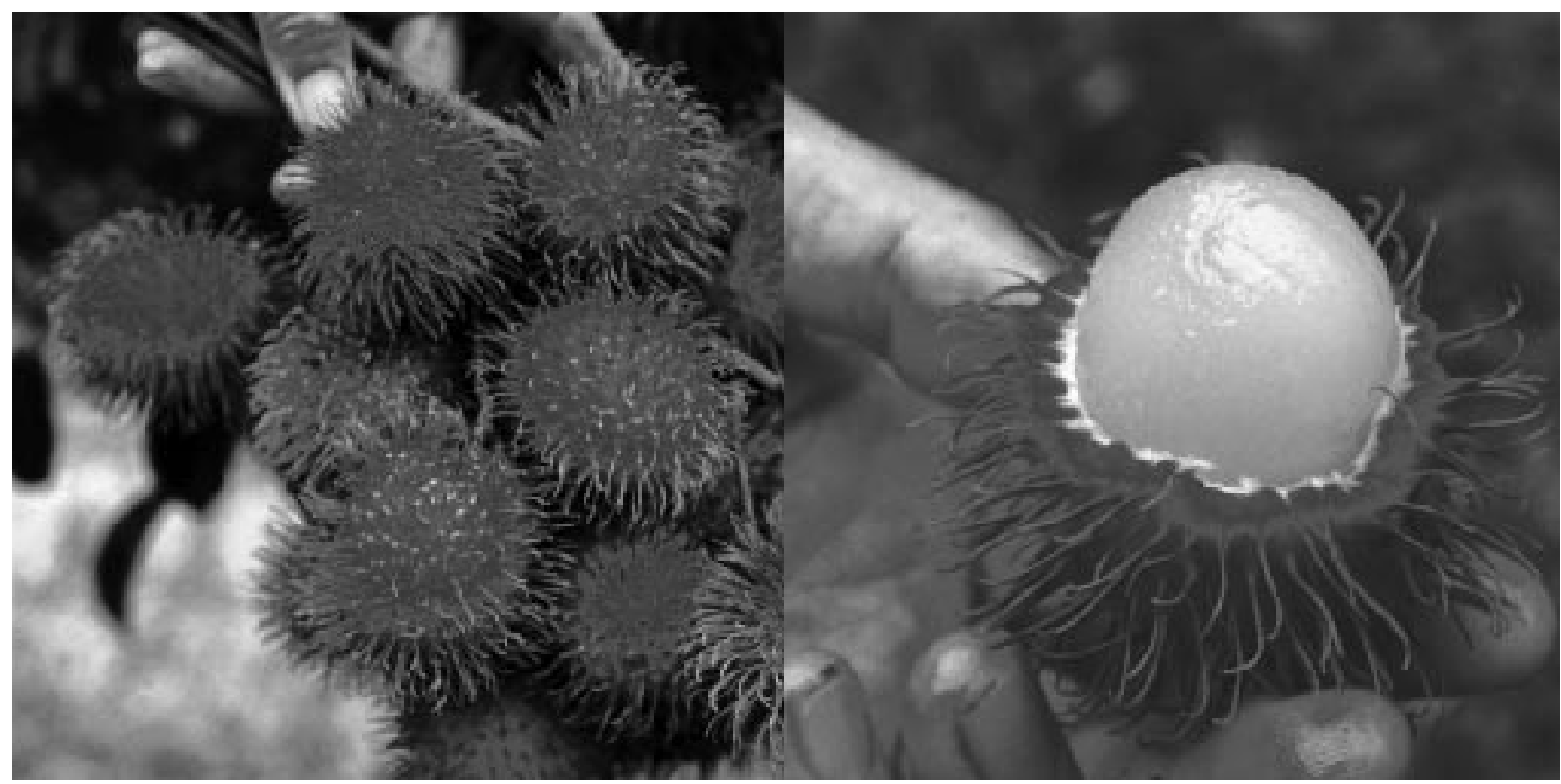

Fig 1. (left) Panicle of rambutans, cultivar R167; (right) rambutan with pericarp removed to expose aril.

minimum fruit core temperature by $>5{ }^{\circ} \mathrm{C}$. Dewpoint temperature inside the chamber was not controlled so that the highest humidity possible during treatment could be obtained. A typical HFA temperature profile is shown in Fig. 2. After heating, fruit were immediately dipped into running tap water at $20^{\circ} \mathrm{C}$ until the fruit core temperature dropped to $25^{\circ} \mathrm{C}$ or less. Fruit were then air-dried and packed for storage at $10^{\circ} \mathrm{C}$.

Irradiation treatment. After being packed in perforated plastic bags, placed in fiberboard boxes, and hand-carried on the flight to Oahu, fruit were irradiated at the Hawaii Research Irradiator at the Univ. of Hawaii at Manoa. The Irradiator uses a ${ }^{60} \mathrm{Co}$ source of gamma radiation, and the dose rate at the time of the tests averaged $5.3 \mathrm{~Gy} \cdot \mathrm{min}^{-1}$. Fruit in the perforated plastic bags were treated at a target dose of $250 \mathrm{~Gy}(0.25 \mathrm{kGy})$. After treatment, samples were repacked and hand-carried back to the USDA laboratory in Hilo. Gafchromic film dosimeters (ISP, Wayne, N.J.) were read with a spectrophotometer (model 550, PerkinElmer, Oak Brook, Ill.) at 500-nm absorbance to verify dose accuracy in each replicate. Film dosimeters were calibrated using alanine dosimeter standards supplied and quantified by the National Physical Laboratory, Middlesex, U.K. Over the course of the study, calculated doses ranged from 225 to $271 \mathrm{~Gy}$, for a maximum/minimum dose ratio of 1.2.

Quality determination. Fruit quality determinations were performed before treatment and 4,8 , and $12 \mathrm{~d}$ after treatment (equivalent to 6,10 , and $14 \mathrm{~d}$ after harvest, respectively) and placement in storage at $10^{\circ} \mathrm{C}$ with relative humidity at $80 \%$. Quality evaluations included Hunter colorimeter measurements, ${ }^{\circ} \mathrm{Brix}, \mathrm{pH}$, total acidity, and heuristic taste comparisons

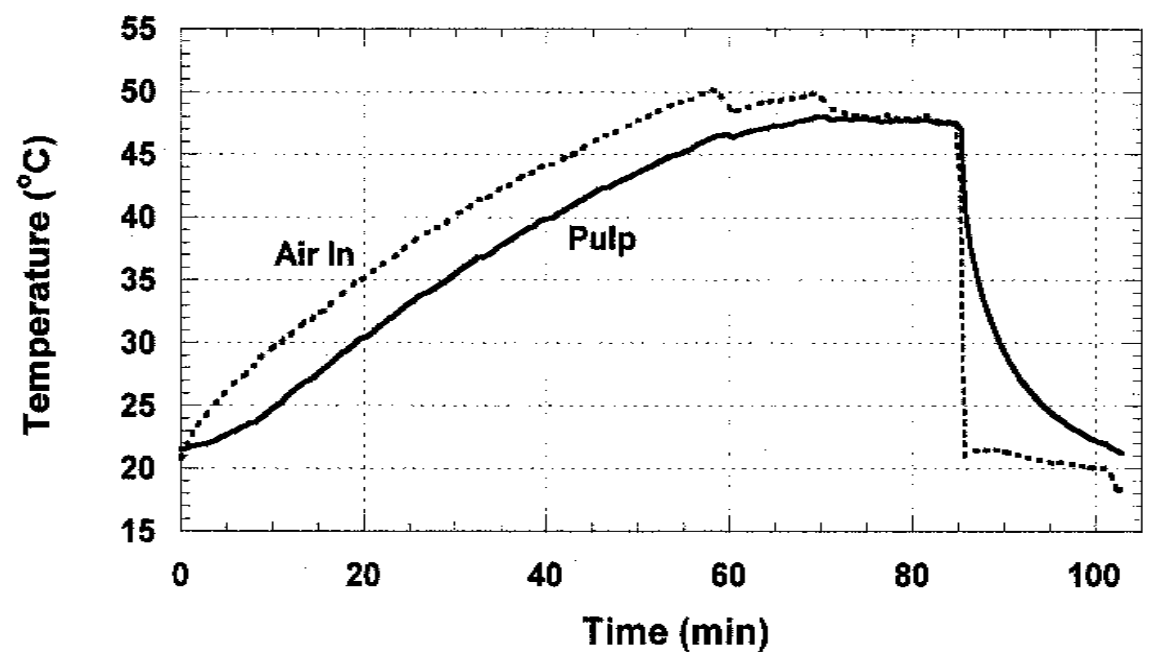

Fig. 2. Temperature profile for fruit subjected to hot forced-air treatment and subsequent cooling in an ambient temperature water bath.

and visual ratings of external appearance. External appearance and taste were rated by three people with experience in grading rambutan and averaged for each fruit. Thirty fruit were evaluated per replicate on the day of fruit arrival ( $2 \mathrm{~d}$ after harvest), and 30 fruit/replicate were evaluated for each treatment at the three storage intervals. External appearance ratings were based on the degree of browning of the spinterns and outer surface of the pericarp: 1 = (best) no spinterns darkened; $2=$ all spinterns darkened; $3=$ all spinterns darkened and pericarp with minor, undefined areas of darkening; $4=$ all spinterns darkened and $50 \%$ or less of the pericarp surface area distinctly darkened; $5=$ (worst rating) all spinterns darkened and $>50 \%$ of the pericarp distinctly darkened. Formal grades and standards have not been developed for rambutan in Hawaii, but an external appearance rating of 3 or higher would probably indicate reduced commercial acceptability. Quantitative measurements of the external color of the pericarp (including spinterns) were made using a HunterLab LabScan spectrocolorimeter (Hunter Associates Laboratory, Reston, Va.), calibrated to a standard pink plate $\mathrm{L}^{*} \mathrm{a}$ *b color system. Measurements were taken across an area $\approx 17 \mathrm{~mm}^{2}$ with diffuse illumination at a viewing angle of $10^{\circ}$ under Commission Internationale de l'Eclairage (CIE) illuminant C conditions. Color values of 30 fruit per treatment were recorded at four equidistant locations around the equator of each fruit and averaged. Hunter $\mathrm{L}$, $\mathrm{a}$, and $\mathrm{b}$ values were converted to the Cielab $\mathrm{L}^{*}$ (darkness), $\mathrm{a}^{*}$, and $\mathrm{b}^{*}$ scale, and chroma $\left(\mathrm{C}^{*}\right.$, color intensity) and hue $\left(\mathrm{h}^{\circ}\right)$ color values were calculated (McGuire, 1992). Fifteen of the fruit were then used for chemical analysis. The juice of each fruit was expressed individually by pressing through a garlic press with 1mm-diameter openings. The ${ }^{\circ}$ Brix was directly measured using two to three drops of 
juice placed on a handheld refractometer(Atago ATC-1E, Daigger \& Co., Inc., Lincolnshire, Ill.). The initial $\mathrm{pH}$ of the juice of each fruit was then measured, after which a 2-mL aliquot was diluted with $10 \mathrm{~mL}$ of distilled water and titrated to an endpoint of $\mathrm{pH} 8.1$ using $0.02 \mathrm{~N}$ $\mathrm{NaOH}$. Percent acidity was based on meq citric acid. The remaining 15 fruit were used for taste evaluations. The taste scale for ratings was: 1 = excellent; 2 = acceptable; 3 = offflavors; $4=$ highly distasteful. An additional 10 fruit per treatment per replicate of each cultivar were held in storage at $10^{\circ} \mathrm{C}$ in plastic bags and weighed 4,8 , and $12 \mathrm{~d}$ posttreatment to measure weight loss.

Data analysis. A two-way analysis of variance (ANOVA) procedure using the standard least squares model was used to test for differences in treatment, storage time, and the treatment $\times$ storage time interaction for each cultivarindependently (SAS Institute, 1997). When the effect of quarantine treatment was significant, means separations were done using the Tukey-Kramer HSD test at $P \leq 0.05$.

\section{Results}

Significant quality differences between quarantine treatments were observed in both cultivars. Treatment effects on chroma $\left(\mathrm{C}^{*}\right)$ and taste were significant for 'R167' (Table 1). At 4,8 , and 12 d posttreatment HFA fruit had the lowest $C^{*}$ values. The $C^{*}$ values for HFA fruit were significantly lower (fruit were less intensely colored) than those of controls after 4 to $8 \mathrm{~d}$ storage, but not significantly different from those of IRR fruit. The $\mathrm{C}^{*}$ values for IRR fruit were significantly lower than those of control fruit after $4 \mathrm{~d}$, but not after $8 \mathrm{~d}$ of storage. After $8 \mathrm{~d}$ of storage, the taste of HFA fruit was significantly less acceptable than that of irradiated fruit, but not significantly different from that of control fruit. However, taste was rated as acceptable for all treatments throughout the trial. The effect of sampling time was significant for C*, weight loss, external appearance, and taste, and all parameters signaled a general decline in fruit quality with increasing storage time.
External appearance ratings for HFA fruit were numerically highest (the least desirable) on all dates. External appearance for all treatments was acceptable after 4 and $8 \mathrm{~d}$ of storage but unacceptable (ratings $\geq 3$ ) after $12 \mathrm{~d}$.

For 'R134', treatment effects were significant for pericarp color $\left(\mathrm{L}^{*}, \mathrm{C}^{*}\right), \mathrm{pH}$, acidity, external appearance, and taste (Table 2). The HFA fruit were significantly darker (lower $\mathrm{L}^{*}$ ) and less intensely colored (lower $\mathrm{C}^{*}$ ) than IRR or nontreated fruit after 4 and $8 \mathrm{~d}$ of posttreatment storage. After $8 \mathrm{~d}$, pH of HFA fruit was significantly higher than that of IRR or nontreated fruits. Acidity was consistently lowest in the HFA treatment, and after $8 \mathrm{~d}$ of storage acidity was significantly lower in HFA fruit than in IRR fruit. The most significant result was that the external appearance of 'R134' fruit treated with HFA was unacceptable after $4 \mathrm{~d}$ of storage whereas IRR fruit remained acceptable for 4 to $8 \mathrm{~d}$ of storage after treatment. External appearance for all treatments was unacceptable (ratings $\geq 3$ ) after $12 \mathrm{~d}$ of storage. Taste ratings were consistently

Table 1. 'R167' rambutan quality at various intervals after treatment with hot forced-air (HFA) or irradiation (IRR).

\begin{tabular}{|c|c|c|c|c|c|c|c|c|c|c|}
\hline \multirow{2}{*}{$\begin{array}{l}\text { Days } \\
\text { after treatment }{ }^{z}\end{array}$} & \multirow[b]{2}{*}{ Treatment } & \multicolumn{3}{|c|}{ Pericarp color } & \multirow{2}{*}{$\begin{array}{c}\mathrm{Wt} \\
\text { loss }(\%)\end{array}$} & \multirow[b]{2}{*}{${ }^{\circ}$ Brix } & \multirow[b]{2}{*}{$\mathrm{pH}$} & \multirow{2}{*}{$\begin{array}{c}\text { Acidity } \\
(\%)\end{array}$} & \multirow{2}{*}{$\begin{array}{c}\text { External } \\
\text { appearance }^{y}\end{array}$} & \multirow[b]{2}{*}{ Taste $^{\mathrm{x}}$} \\
\hline & & $\mathrm{L}^{*}$ & $\mathrm{C}^{*}$ & $\mathrm{~h}^{\circ}$ & & & & & & \\
\hline Initial & & 33.1 & 39.0 & 31.3 & --- & 16.9 & 4.1 & 0.48 & 1.8 & 1.2 \\
\hline \multirow[t]{3}{*}{4} & Control & 29.3 & $37.0 \mathrm{a}^{\mathrm{w}}$ & 32.4 & 3.0 & 16.3 & 4.1 & 0.48 & 2.0 & $1.5 \mathrm{a}$ \\
\hline & HFA & 27.6 & $33.6 \mathrm{~b}$ & 31.1 & 2.0 & 16.4 & 4.2 & 0.42 & 2.2 & $1.6 \mathrm{a}$ \\
\hline & IRR & 28.9 & $34.7 \mathrm{~b}$ & 31.2 & 2.7 & 16.7 & 4.2 & 0.46 & 2.1 & $1.5 \mathrm{a}$ \\
\hline \multirow[t]{3}{*}{8} & Control & 27.6 & $34.7 \mathrm{a}$ & 31.7 & 4.2 & 17.0 & 4.1 & 0.45 & 2.2 & $1.6 \mathrm{ab}$ \\
\hline & HFA & 26.0 & $31.6 \mathrm{~b}$ & 30.9 & 3.1 & 16.6 & 4.2 & 0.41 & 2.6 & $1.8 \mathrm{~b}$ \\
\hline & IRR & 28.1 & $33.4 \mathrm{ab}$ & 31.8 & 4.0 & 16.7 & 4.2 & 0.44 & 2.3 & $1.5 \mathrm{a}$ \\
\hline \multirow[t]{3}{*}{12} & Control & 24.4 & $30.4 \mathrm{a}$ & 32.5 & 5.4 & 17.0 & 4.2 & 0.43 & 3.7 & $1.7 \mathrm{a}$ \\
\hline & HFA & 22.5 & $25.5 \mathrm{a}$ & 32.7 & 4.4 & 16.3 & 4.3 & 0.40 & 4.0 & $2.1 \mathrm{a}$ \\
\hline & IRR & 25.3 & $29.4 \mathrm{a}$ & 32.8 & 5.2 & 16.4 & 4.2 & 0.44 & 3.6 & $1.6 \mathrm{a}$ \\
\hline \multicolumn{11}{|c|}{ Main effects and interaction } \\
\hline & Day (D) & NS & $*$ & NS & $*$ & NS & NS & NS & $*$ & $*$ \\
\hline & Treatment $(\mathrm{T})$ & NS & $*$ & NS & NS & NS & NS & NS & NS & $*$ \\
\hline & $\mathrm{D} \times \mathrm{T}$ & $*$ & NS & NS & NS & NS & NS & NS & NS & NS \\
\hline
\end{tabular}

${ }^{2}$ Temperature of fruit storage for the duration of the experiment was $10{ }^{\circ} \mathrm{C}$; values are means of four replicates.

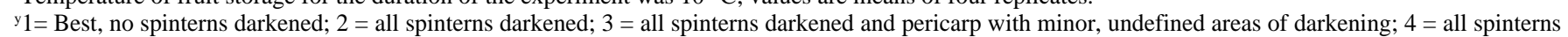
darkened and $50 \%$ or less of the pericarp surface area distinctly darkened; $5=$ worst, all spinterns darkened and $>50 \%$ of the pericarp distinctly darkened.

${ }^{\mathrm{x}} 1$ = Excellent; 2 = acceptable; 3 = off-flavors; 4 = highly distasteful.

${ }^{w}$ Mean separation within columns and times by Tukey-Kramer HSD $(P \leq 0.05)$.

Ns, *Nonsignificant or significant at $P \leq 0.05$.

Table 2. 'R134' rambutan quality at various intervals after treatment with hot forced-air (HFA) or irradiation (IRR).

\begin{tabular}{|c|c|c|c|c|c|c|c|c|c|c|}
\hline \multirow{2}{*}{$\begin{array}{l}\text { Days } \\
\text { after treatment }{ }^{\mathrm{z}}\end{array}$} & \multirow[b]{2}{*}{ Treatment } & \multicolumn{3}{|c|}{ Pericarp color } & \multirow{2}{*}{$\begin{array}{c}\mathrm{Wt} \\
\text { loss }(\%)\end{array}$} & \multirow[b]{2}{*}{${ }^{\circ}$ Brix } & \multirow[b]{2}{*}{$\mathrm{pH}$} & \multirow{2}{*}{$\begin{array}{c}\text { Acidity } \\
(\%)\end{array}$} & \multirow{2}{*}{$\begin{array}{c}\text { External } \\
\text { appearance }^{y}\end{array}$} & \multirow[b]{2}{*}{ Taste $^{\mathrm{x}}$} \\
\hline & & $\mathrm{L}^{*}$ & $\mathrm{C}^{*}$ & $\mathrm{~h}^{\circ}$ & & & & & & \\
\hline Initial & & 33.2 & 39.8 & 32.1 & --- & 18.6 & 4.0 & 0.46 & 1.5 & 1.2 \\
\hline \multirow[t]{3}{*}{4} & Control & $30.7 \mathrm{a}^{\mathrm{w}}$ & $34.1 \mathrm{a}$ & 34.9 & 3.1 & 18.4 & $4.0 \mathrm{a}$ & $0.48 \mathrm{a}$ & $1.8 \mathrm{a}$ & $1.2 \mathrm{a}$ \\
\hline & HFA & $27.2 \mathrm{~b}$ & $30.1 \mathrm{~b}$ & 34.2 & 2.2 & 18.6 & $4.2 \mathrm{~b}$ & $0.43 \mathrm{a}$ & $3.1 \mathrm{~b}$ & $1.4 \mathrm{a}$ \\
\hline & IRR & $30.7 \mathrm{a}$ & $32.3 \mathrm{a}$ & 34.9 & 2.3 & 18.7 & $4.1 \mathrm{ab}$ & $0.47 \mathrm{a}$ & $1.9 \mathrm{a}$ & $1.5 \mathrm{a}$ \\
\hline \multirow[t]{3}{*}{8} & Control & $29.6 \mathrm{a}$ & $32.0 \mathrm{a}$ & 34.5 & 4.2 & 18.6 & $4.1 \mathrm{a}$ & $0.45 \mathrm{ab}$ & $2.2 \mathrm{a}$ & $1.3 \mathrm{ab}$ \\
\hline & HFA & $26.6 \mathrm{~b}$ & $26.8 \mathrm{~b}$ & 34.2 & 3.4 & 18.5 & $4.3 \mathrm{~b}$ & $0.40 \mathrm{~b}$ & $3.4 \mathrm{~b}$ & $1.6 \mathrm{~b}$ \\
\hline & IRR & $29.9 \mathrm{a}$ & $30.2 \mathrm{a}$ & 34.1 & 3.5 & 18.4 & $4.1 \mathrm{a}$ & $0.46 \mathrm{a}$ & $2.3 \mathrm{a}$ & $1.3 \mathrm{a}$ \\
\hline \multirow[t]{3}{*}{12} & Control & $27.0 \mathrm{a}$ & $27.4 \mathrm{a}$ & 36.3 & 5.7 & 18.5 & $4.0 \mathrm{a}$ & $0.50 \mathrm{a}$ & $3.7 \mathrm{a}$ & $1.6 \mathrm{a}$ \\
\hline & HFA & $24.9 \mathrm{a}$ & $22.9 \mathrm{~b}$ & 35.3 & 4.9 & 18.6 & $4.2 \mathrm{a}$ & $0.42 \mathrm{~b}$ & $3.9 \mathrm{a}$ & $2.0 \mathrm{~b}$ \\
\hline & IRR & $27.6 \mathrm{a}$ & $26.7 \mathrm{ab}$ & 34.7 & 5.1 & 18.8 & $4.2 \mathrm{a}$ & $0.44 \mathrm{ab}$ & $3.3 \mathrm{a}$ & $1.7 \mathrm{ab}$ \\
\hline \multicolumn{11}{|c|}{ Main effects and interactions } \\
\hline & Day (D) & NS & $*$ & NS & $*$ & NS & NS & NS & $*$ & $*$ \\
\hline & Treatment $(\mathrm{T})$ & $*$ & $*$ & NS & NS & NS & $*$ & $*$ & $*$ & $*$ \\
\hline & $\mathrm{D} \times \mathrm{T}$ & NS & NS & NS & NS & NS & NS & NS & $*$ & NS \\
\hline
\end{tabular}

${ }^{2}$ Temperature of fruit storage for the duration of the experiment was $10{ }^{\circ} \mathrm{C}$; values are means of four replicates.

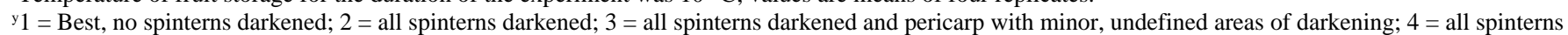
darkened and $50 \%$ or less of the pericarp surface area distinctly darkened; $5=$ worst, all spinterns darkened and $>50 \%$ of the pericarp distinctly darkened.

${ }^{\mathrm{x}} 1$ = Excellent; 2 = acceptable; 3 = off-flavors; 4 = highly distasteful.

${ }^{w}$ Mean separation within columns and times by Tukey-Kramer HSD $(P \leq 0.05)$.

Ns, *Nonsignificant or significant at $P \leq 0.05$. 
highest (least acceptable) in the HFA treatment, and after $8 \mathrm{~d}$ of storage the taste rating of HFA fruit was significantly worse than that of irradiated fruit. However, fruit taste was rated as acceptable throughout the test for all treatments. The effect of sampling time was significant for $\mathrm{C}^{*}$, weight loss, external appearance, and taste, all reflecting the general decline in fruit quality with increasing storage time. Note that the 'Brix reading of 'R134' was 1.5 to 2 percentage points greater than that of ' $\mathrm{R} 167$ '.

\section{Discussion}

In general, rambutans have a short storage life under ambient conditions, and prolonging shelf life could be commercially advantageous. A decline in external appearance of rambutan fruit after harvest is attributable to desiccation and superficial physiological browning (Landrigan et al., 1996a). At ambient temperatures, severe browning of the spinterns and fruit surface is apparent 2 to $3 \mathrm{~d}$ after harvest. A rambutan fruit has $\approx 400$ spinterns and many stomata per spintern (Lam et al., 1987). The rapid desiccation of the spinterns may be related to the high surface: volume ratio and the poor closing capability of stomata (Landrigan et al., 1994). Various studies have suggested that reducing weight loss from desiccation is crucial in preventing browning (Landrigan et al., 1996a, 1996b; Paull et al., 1995). Desiccation can be reduced by storage at low temperatures and high relative humidity. Physiological browning may be caused by degradation of anthocyanin pigments from increased polyphenol oxidase, as in litchi (Underhill and Critchley, 1992), or by oxidation of phenols to quinones that polymerize to form brown pigments (Mayer and Harel, 1979). Mechanical damage, such as bending of spinterns, can hasten desiccation and browning in fruits (Landrigan et al., 1996b).

We attempted to minimize desiccation and browning of rambutans in our experiment by holding fruit at $10^{\circ} \mathrm{C}$ in perforated plastic bags (to maintain high humidity). Although weight loss was held to $<6 \% 12 \mathrm{~d}$ posttreatment, the spinterns of fruit had darkened regardless of treatment and cultivar, and the surface of fruit had turned a dull red $4 \mathrm{~d}$ after treatment (i.e., 6 $\mathrm{d}$ after harvest); distinct brown blotches had appeared $8 \mathrm{~d}$ posttreatment; and browning typically covered a significant portion of the pericarp $12 \mathrm{~d}$ posttreatment. Nevertheless, external appearance remained acceptable after $8 \mathrm{~d}$ of posttreatment storage ( $10 \mathrm{~d}$ after harvest). The minimum time from harvest in Hawaii to delivery to a mainland grocer is $6 \mathrm{~d}$, resulting in a relatively small window of opportunity for marketing high-quality fruit. Fortunately, taste remains acceptable after the attractive red color of rambutan fruit diminishes.

Many fruit used in our experiment had bent spinterns caused by packaging and shipment to our laboratory. This is a typical condition for rambutans exported from Hawaii. Bending of spinterns may have increased the rate of browning in our study; spinterns typically had darkened bases before treatment ( $2 \mathrm{~d}$ after harvest) and were uniformly brown $4 \mathrm{~d}$ later, regardless of treatment.

The two quarantine treatments compared in our study were developed to kill Hawaii's fruit fly pests prior to export of fruit, and treatment protocols are either approved (IRR) or soon to be approved (HFA) for exporting rambutans. Other HFA and IRR treatment conditions might have produced results different from those we observed. During the HFA treatment used in our experiment, condensation occurs on the fruit surface, making this a vapor forced-air treatment (sensu Shellie, 1999). Rambutan fruit might have been more tolerant of a moist forced-air treatment, where the dewpoint temperature in the chamber is maintained below the surface temperature of the fruit to prevent condensation (Shellie and Mangan, 1998). However, the heat transfer coefficient for moist forced-air is lower than for vapor forced-air, resulting in a slower heating rate, and, therefore, a moist forced-air treatment might need to be of longer duration to achieve an equal level of fruit fly mortality. The effect on quality of a longer heat treatment without fruit surface condensation is difficult to predict.

Likewise, a higher irradiation dose could conceivably have been more harmful than the one used in our experiment. A 3:1 maximum/ minimum dose ratio is often cited (e.g., Hallman, 1999) as typical for the large medical-products irradiators normally used to treat fresh fruit commercially. A previous study has shown that irradiation doses up to $900 \mathrm{~Gy}(0.9$ kGy) had no effect on the chemical, physical, or sensory attributes of 'R167' rambutans after $9 \mathrm{~d}$ of storage (Moy et al., 1999). On the basis of these data we elected to include only one irradiation dose in our tests. Also, irradiators specifically designed to treat relatively small volumes of fresh produce, such as the ebeam system at the Univ. of Florida and the ebeam/x-ray system recently built in Hawaii, deliver a more uniform dose, with variation comparable to that observed in our experiment $(\mathrm{max} / \mathrm{min} \approx 1.2$ to 1.5$)$.

For 'R134' rambutans, decline in fruit appearance was accelerated more by HFA than by IRR. Fruit quality differences between HFAand IRR-treated fruit were more dramatic for 'R134' than for 'R167'. For 'R167' rambutans, external appearance ratings were numerically higher (lower quality) for HFA than for IRR or control fruit, but differences were nonsignificant. Therefore, under our conditions, IRR was superior to HFA as a quarantine treatment based on maintenance of fruit quality. However, other market factors in Hawaii, such as the availability of treatment facilities on different islands and costs, will ultimately contribute to the choice of a quarantine treatment.

\section{Literature Cited}

Gaffney, J.J. and J.W. Armstrong. 1990. Hot forcedair research facility for heating fruits for insect quarantine treatments. J. Econ. Entomol. 83:1959-1964.

Hallman, G.J. 1999. Ionizing radiation quarantine treatments against tephritid fruit flies. Postharvest Biol. Technol. 16:93-106.

Lam, P.F., S. Kosiyachinda, M.C.C. Lizada, D.B Mendoza Jr., S. Prabawati, and S.K. Lee. 1987. Postharvest physiology and storage of rambutan, p. 39-50. In: P.F. Lam and S. Kosiyachinda (eds.). Rambutan: Fruit development, postharvest physiology and marketing in ASEAN. ASEAN Food Handling Bur., Kuala Lumpur, Malaysia.

Landrigan, M., S.C. Morris, and K.S. Gibb. 1996a. Relative humidity influences postharvest browning in rambutan (Nephelium lappaceum L.). HortScience 31:417-418.

Landrigan, M., S.C. Morris, and B.W. McGlasson. 1996b. Postharvest browning of rambutan is a consequence of water loss. J. Amer. Soc. Hort. Sci. 121:730-734.

Landrigan, M., V. Sarafis, S.C. Morris, and B.W McGlasson. 1994. Structural aspects of rambu$\tan$ (Nephelium lappaceum L.) fruits and their relationship to postharvest browning. J. Hort. Sci. 69:571-579.

Mayer, A.M. and E. Harel. 1979. Polyphenol oxidases in plants. Phytochemistry 18:193-215.

McGuire, R.G. 1992. Reporting of objective color measurements. HortScience 27:1254-1255.

Moy, J.H., R.E. Paull, X. Bian, R. Chung, and L. Wong. 1999. Quality of tropical fruit irradiated as a quarantine treatment, p. 45-53. In: J.H. Moy and L. Wong (eds.). The use of irradiation as a quarantine treatment of food and agricultural commodities. Proc. Wkshp., Honolulu, Hawaii, 10-12 Nov. 1997

Nakasone, H.Y. and R.E. Paull. 1998. Tropical fruits. CAB Intl., Wallingford, U.K.

Paull, R.E. and N.J. Chen. 1987. Changes in longan and rambutan during postharvest storage. HortScience 22:1303-1304.

Paull, R.E., M.E.Q. Reyes, and M.U. Reyes. 1995 Litchi and rambutan insect disinfestation: Treatments to minimize induced pericarp browning. Postharvest Biol. Technol. 6:139-148.

SAS Institute. 1997. JMP user's guide. SAS Inst., Cary, N.C.

Shellie, K.C. 1999. Citrus heat treatments for disinfesting fruit flies, p. 149-161. In: M. Schirra (ed.). Advances in postharvest diseases and disorders control of citrus fruit. Res. Signpost, Trivandrum, India.

Shellie, K.C. and R.L. Mangan. 1998. Navel orange tolerance to heat treatments for disinfesting Mexican fruit fly. J. Amer. Soc. Hort. Sci. 123:288-293.

Underhill, S.J.R. and C. Critchley. 1992. The physiology and anatomy of lychee (Litchi chinensis) pericarp during fruit development. J. Hort. Sci. 67:437-444.

Watson, B.J. 1988. Rambutan cultivars in north Queensland. Queensland Agr. J. 114:37-41.

Zee, F.T.P., H.T. Chan, and C.-R. Yen. 1998. Lychee, longan, rambutan and pulasan, p. 290-335. In: P.E. Shaw, H.T. Shaw, and S. Nagy (eds.). Tropical and subtropical fruits. Agscience, Auburndale, Fla. 